\title{
Efektivitas Pemeriksaan Prokalsitonin Sebagai Petanda Dini Sepsis pada Anak
}

\author{
Arie L. Runtunuwu, Jeanette I. C. Manoppo, T.H. Rampengan, Novie H. Rampengan, \\ Suyanto Kosim \\ Bagian Ilmu Kesehatan Anak Fakultas Kedokteran Universitas Sam Ratulangi/RSU Prof. Dr. R. D. \\ Kandou Manado
}

\begin{abstract}
Latar belakang. Sepsis merupakan penyebab utama kematian bayi dan anak di rumah sakit. Diagnosis awal dan pengobatan segera, merupakan cara terbaik untuk penanganan sepsis. Pemeriksaan biakan darah merupakan cara paling efektif mendiagnosis sepsis namun membutuhkan waktu cukup lama, sehingga diperlukan pemeriksaan tambahan untuk mendiagnosis sepsis dengan cepat dan akurat yaitu prokalsitonin. Tujuan. Mendapatkan cara mudah dan cepat untuk mendiagnosis sepsis.

Metode. Pemeriksaan uji diagnostik dengan pendekatan cross sectional dilakukan pada 56 anak yang dirawat di Bagian Anak RSU Prof. Dr. R. D. Kandou Manado dari Oktober 2005 - Januari 2006, usia 1 bulan - 13 tahun dengan diagnosis sepsis sesuai modifikasi kriteria Bone.

Hasil. Dilakukan penilaian sensitivitas, spesifitas, nilai duga positif dan nilai duga negatif. Dari 56 sepsis laki-laki 33 (58,9\%) dan perempuan 23 (41,1\%). Analisis statistik menggunakan uji Z untuk prokalsitonin didapatkan sensitivitas $80,0 \%$, spesifisitas $11,54 \%$ dengan nilai duga positif $51,1 \%$ serta nilai duga negatif 33,3\%.
\end{abstract}

Kesimpulan. Pemeriksaan prokalsitonin dapat digunakan sebagai alat diagnosis dini sepsis pada bayi dan anak. (Sari Pediatri 2008; 9(5):319-22).

Kata kunci: prokalsitonin, diagnosis dini sepsis

epsis adalah penyakit sistemik yang disebabkan oleh penyebaran mikroba atau toksin ke dalam aliran darah dan menimbulkan respons sistemik. Sepsis juga merupakan kedaruratan

\footnotetext{
Alamat korespondensi

Dr. Ari Lukas Runtunuwu, SpA. Bagian Ilmu Kesehatan Anak FK UNSRAT/RSU Prof. Dr. R.D. Kandou Manado. Telepon: (0431) 821652; Fax.: (0431) 859091. Rumah: Jl. Santu Yoseph No. 19, Manado 95115. Telepon: (0431) 827209; Hp: 085256215818.
}

medik sehingga memerlukan pengobatan segera untuk menurunkan angka kematian. ${ }^{1-3}$ Sepsis selalu terjadi pada pasien dengan kondisi kritis dan angka kematiannya tinggi terutama di negara yang sedang berkembang. ${ }^{4,5}$

Insiden sepsis pada anak 1-10 per 1000 kelahiran hidup dengan mortalitas 13\%-50\%. Di Amerika Serikat sepsis merupakan penyebab kematian urutan ke-13 pada anak yang berumur di atas 1 tahun dan dalam satu tahun dijumpai 500.000 - 750.000 kasus 
dan 50\%-70\% dilaporkan bertahan hidup. ${ }^{6,7}$ Di negara kita angka kematian karena sepsis masih sangat tinggi 50\%-70\% dan apabila terjadi syok septik serta disfungsi organ multipel kematian meningkat (80\%). ${ }^{4}$ Diagnosis sepsis seringkali sulit ditegakkan dalam waktu singkat karena hasil biakan kuman yang merupakan baku emas diagnosis didapat setelah beberapa hari. ${ }^{4-11}$ Uji diagnostik yang ideal jarang ditemukan terutama uji yang memberi hasil negatif pada subjek sehat. ${ }^{12}$

Pemeriksaan prokalsitonin (PCT) serum merupakan salah satu pemeriksaan yang dapat digunakan untuk mendignosis sepsis pada bayi dan anak, karena PCT merupakan surrogate marker untuk infeksi. Hasil PCT dapat dipakai baik sebagai alat diagnostik maupun prognostik. ${ }^{13,14}$

\section{Metode}

Penelitian dilakukan di Bagian Ilmu Kesehatan Anak Fakultas Kedokteran Universitas Sam Ratulangi/RSU Prof. Dr. R. D. Kandou Manado dari Oktober 2005 Januari 2006. Desain penelitian menggunakan uji diagnostik dengan pendekatan cross sectional. Variabel yang diuji adalah PCT dengan menggunakan baku emas biakan darah.

Populasi penelitian adalah semua pasien yang menderita sepsis yang dirawat di Bagian Ilmu Kesehatan Anak Fakultas Kedokteran Universitas Sam Ratulangi/RSU Prof. Dr. R. D. Kandou Manado. Subjek diduga secara klinis menderita sepsis yang memenuhi kriteria inklusi: berusia 1 bulan - 13 tahun, diagnosis sepsis sesuai kriteria modifikasi Bone, belum mendapat antibiotik atau mendapat antibiotik kurang dari 3 hari, serta orang tua setuju dan bersedia mengisi formulir penelitian. Kriteria ekslusi apabila pasien menderita penyakit keganasan, gizi buruk, keadaan imunokompromais, riwayat trauma, dan riwayat pembedahan.

Besar sampel dihitung berdasarkan perhitungan rumus besar sampel didapatkan 56, dengan $\alpha 0,05$, nilai sensitivitas dan spesifisitas berdasarkan referensi masing-masing $80 \%$ serta penyimpangan pada sensitivitas dan spesifisitas masing-masing 15\%. Biakan darah merupakan baku emas dalam mendiagnosis sepsis. Dikatakan positif bila didapatkan koloni kuman dalam biakan. Pemeriksaan prokalsitonin (PCT) dilakukan dengan cara meneteskan serum pasien pada tes strip. Setelah 30 menit akan terlihat hasil yang dinyatakan dalam intesitas warna yang disesuaikan dengan kartu referensi, $<0,5 \eta \mathrm{g} / \mathrm{ml}=$ normal, $0,5-2$ $\eta \mathrm{g} / \mathrm{ml}=$ sepsis, $2-10 \eta \mathrm{g} / \mathrm{ml}=$ sepsis karena infeksi bakteri, dan $>10 \eta \mathrm{g} / \mathrm{ml}=$ infeksi bakteri berat dengan SIRS.

Data dianalisis untuk mendapatkan sensitivitas, spesifisitas, akurasi, nilai duga positif dan nilai duga negatif. Kesesuaian hasil pemeriksaan PCT dan biakan darah diuji dengan koefisien korelasi Phi dan untuk pengujian hipotesis digunakan uji $\mathrm{Z}$.

\section{Hasil}

Dari 56 pasien yang didiagnosis sepsis berdasarkan modifikasi kriteria Bone, dijumpai 30 dengan biakan darah positif. Jenis kelamin laki-laki 33 (58,99\%). Umur pasien terbanyak <2 tahun 39 (69,6\%). Status gizi terbanyak $40(71,4 \%)$ dengan gizi baik. Pendidikan orangtua terbanyak adalah SD dan SMP $40(71,4 \%)$. Jumlah leukosit $>10.000 / \mathrm{mm}^{3}$ didapatkan pada 52 (92,9\%) anak. Lama demam di rumah terbanyak $\leq 5$ hari $39(69,6 \%)$. Tiga puluh satu $(55,4 \%)$ mempunyai suhu $38-39^{\circ} \mathrm{C}$ Hasil pemeriksaan PCT tertera pada Tabel 1.

Hasil pemeriksaan PCT pada pasien sepsis dengan biakan darah positif $24(80,0 \%)$ dari 30 kasus (Tabel 2).

Berdasarkan analisis koefisien korelasi Phi untuk mempelajari kesesuaian antara hasil pemeriksaan PCT dengan pemeriksaan biakan darah diperoleh $\pi=0,115$

Tabel 1. Distribusi pasien berdasarkan pemeriksaan PCT

\begin{tabular}{lcc}
\hline Kadar prokalsitonin & Jumlah $(\mathrm{n}=50)$ & Persentase \\
\hline Normal & 9 & 16,1 \\
Sepsis & 16 & 28,6 \\
Sepsis infeksi bakteri & 17 & 30,3 \\
Infeksi bakteri berat & 14 & 25,0 \\
dengan SIRS & & \\
\hline
\end{tabular}

Tabel 2. Distribusi jumlah pasien berdasarkan pemeriksaan PCT dengan biakan darah

\begin{tabular}{lccc}
\hline \multicolumn{4}{c}{ Biakan } \\
\multicolumn{1}{c}{ PCT } & Positif (\%) & Negatif (\%) & Jumlah (\%) \\
\hline Sepsis & $24(80,0)$ & $23(88,5)$ & $47(83,9)$ \\
Normal & $6(20,0)$ & $3(11,5)$ & $9(16,1)$ \\
\hline
\end{tabular}


Tabel 3. Hasil pengujian hipotesis penelitian

\begin{tabular}{lccc}
\hline \multicolumn{1}{c}{ Indikator } & Persentase & Uji Z & $\rho$ \\
\hline Akurasi & 48,21 & $-5,947$ & $<0,001$ \\
Sensitivitas & 80,00 & 0,000 & 0,500 \\
Spesifisitas & 11,54 & $-8,727$ & $<0,001$ \\
\hline
\end{tabular}

dengan $\rho=0,390$. Hasil ini menyatakan bahwa hasil kedua pemeriksaan ini untuk mendiagnosis sepsis pada bayi dan anak tidak terdapat perbedaan yang bermakna $(\rho=0,390)$.

Hasil uji $Z$ yang digunakan untuk menguji akurasi, sensitivitas dan spesifisitas PCT tertera pada Tabel 3.

Tabel 3 ini menunjukkan bahwa nilai akurasi PCT berbeda bermakna $(\rho<0,001)$, hasil uji sensitivitas PCT dengan baku emas pemeriksaan biakan darah tidak berbeda bermakna dengan nilai sensitivitas PCT 80,0 \% $(\rho=0,500)$, dan hasil uji spesifisitas PCT dengan baku emas pemeriksaan biakan darah berbeda bermakna dengan spesifisitas PCT $11,54 \%(\rho<0,001)$.

\section{Diskusi}

Tidak terdapat perbedaan proporsi antara laki-laki dan perempuan, sesuai dengan Watson $\mathrm{dkk}^{,}{ }^{6}$ Proulx $\mathrm{dkk}^{7}$ dan Budiono. ${ }^{15}$ Distribusi umur terbanyak pada kelompok umur 1-2 tahun sebanyak 39 (69,6\%), ini sesuai dengan yang dijumpai oleh Jafari dkk. ${ }^{16}$ Pendidikan orang tua yang terbanyak SD dan SMP yaitu sebanyak $40(71,4 \%)$, ini sesuai dengan yang ditemukan oleh Chairulfatah $\mathrm{A}^{5}$ dan Maar $\mathrm{SP}^{11}$ yaitu pada orang tua yang berpendidikan rendah karena ketidaktahuan mereka terhadap penyakit yang berbahaya sehingga terlambat berobat.

Pemeriksaan PCT ditemukan pada 24 (80\%) dengan biakan positif, sedangkan Budiono $S^{15}$ menemukan 43,75\%. Jumlah leukosit $>10.000 / \mathrm{mm}^{3}$ dijumpai 52 pasien $(92,9 \%)$ sedangkan Putto $\mathrm{dkk}^{17}$ menemukan $67 \%$ pasien sepsis dengan leukosit $>15.000 / \mathrm{mm}^{3}$

Dengan uji $\mathrm{Z}$ yang digunakan untuk menguji hipotesis menunjukkan hasil uji diagnostik PCT dengan baku emas biakan darah didapatkan nilai akurasi berbeda jauh lebih rendah dari $80 \%$. Jadi dengan kata lain nilai akurasi PCT dengan menggunakan baku emas pemeriksaan biakan darah tidak memenuhi akurasi yang tinggi. Namun, hasil uji Z terhadap sensitivitas PCT sama dengan $80 \%$, jadi nilai sensitivitas PCT dengan menggunakan baku emas pemeriksaan biakan darah memiliki nilai sensitivitas yang tinggi. Hasil uji $\mathrm{Z}$ terhadap spesifisitas PCT dengan menggunakan baku emas pemeriksaan biakan darah tidak memiliki nilai spesifisitas yang tinggi ( $\rho$ $<0,001)$. Hal ini menunjukkan bahwa pemeriksaan PCT belum merupakan petanda laboratorium yang baik untuk mendiagnosis sepsis, sebab walaupun memenuhi sensitivitas yang tinggi, namun spesifisitasnya rendah.

Hasil penelitian ini berbeda dengan yang didapatkan oleh O'Connor dkk, ${ }^{13}$ yang menemukan bahwa pada infeksi dini dari sepsis, PCT memberikan sensitivitas sebesar 83\%-100\% dan spesifisitas 70\%-100\% dan pada sepsis infeksi lambat yang terjadi 3-30 hari, PCT memberikan sensitivitas dan spesifisitas sebesar $100 \%$ dalam mengidentifikasi sepsis bakterial. Oberhoffer dkk (dikutip dari O'Connor dkk) mendapatkan nilai sensitivitas PCT $88 \%$ dengan nilai prediktif $57 \%$. O'Connor $\mathrm{dkk}^{13}$ menemukan cut off sebesar $2 \eta \mathrm{g} / \mathrm{ml}$, PCT mempunyai sensitivitas sebesar $91 \%$, spesifisitas sebesar $87 \%$ dan nilai prediktif negatif sebesar $77 \%$ untuk diagnosis sepsis berat. Pada penelitian ini menggunakan pemeriksaan PCT secara semikuantitatif sehingga tidak didapatkan nilai cut off, juga pada penelitian ini pengambilan spesimen biakan darah hanya diambil satu kali, dibandingkan dengan penelitian-penelitian lain seperti O'Connor $\mathrm{dkk}^{13}$ dan Hatherill $\mathrm{dkk}^{18}$ menggunakan dua kali pengambilan spesimen darah sehingga kemungkinan menjaring keberadaan mikroba lebih besar.

Prokalsitonin adalah pertanda yang sangat baik untuk infeksi bakterial berat pada anak. Namun demikian uji ini tidak dapat dijadikan sebagai pemeriksaan baku emas. Nilai prediktif negatif tidak selalu $100 \%$ dan oleh karena itu nilai PCT yang rendah tidak dapat dijadikan sebagai patokan. ${ }^{19,20}$ Menurut Gendrel $^{21}$ dan Lopez ${ }^{20}$ pemeriksaan PCT mempunyai spesifisitas tertinggi untuk infeksi bakteri yaitu sebesar $100 \%$, tetapi sensitivitasnya hanya $69 \%$. Somech $\mathrm{dkk}^{22}$ menemukan nilai PCT sebesar $\geq 1 \mathrm{\eta g} / \mathrm{ml}$ mempunyai sensitivitas dan spesifisitas yang lebih baik dari CRP, IL6 dan Interferon $\alpha$ dalam membedakan infeksi virus dan bakteri.

Keterbatasan penelitian ini dengan menggunakan diagnosis klinis sepsis berdasarkan modifikasi kriteria Bone. Dalam pengalaman klinis tidak semua kriteria 
tersebut terpenuhi, sehingga tidak tertutup kemungkinan terdapat kasus sepsis yang tidak tercakup didalam penilitian ini atau kasus-kasus yang datang dalam keadaan sangat berat sehingga belum sempat dilakukan pengambilan sampel darah pasien sudah meninggal. Keterbatasan sarana dan prasarana untuk biakan darah maka hanya diambil satu kali, media yang tersedia tidak dapat mendeteksi bakteri anaerob maupun bakteri dengan jumlah koloni sedikit.

\section{Kesimpulan}

Pemeriksaan prokalsitonin dapat digunakan sebagai alat diagnosis dini sepsis yang praktis penting dilakukan pada bayi dan anak (sensitivitas tinggi), sehingga dapat diberikan pengobatan secepatnya sambil menunggu hasil biakan darah.

\section{Daftar Pustaka}

1. Goldstein B, Ginoir B, Randolph A. International pediatric sepsis consensus conference: Definitions for sepsis and organ dysfunction in pediatrics. Pediatr Crit Care Med 2005; 6:2-8.

2. Powel KR. Sepsis and shock. Dalam: Behrman RE, Kliegman RM, Jenson HB, penyunting. Nelson Textbook of Pediatrics. Edisi ke-16. WB Saunder Company; 2000. h. 744-51.

3. Hayden WR. Sepsis terminology in pediatrics. J Pediatr 1994;124:657-8.

4. Latief A. Pendekatan diagnosis sepsis. Dalam: Lubis M, Evalina R, Irsa L. Makalah lengkap simposium nasional pediatri gawat darurat VI. Bagian Ilmu Kesehatan Anak Medan: FK USU; 2003. h. 28-35.

5. Chairulfatah A. Sepsis dan syok septik.Dalam:Sumarmo S, Soedarmo P, Hadinegoro SR. Buku ajar Ilmu Kesehatan Anak IDAI. Jakarta: Balai Penerbit FK UI; 2002. h. 391-8.

6. Watson RS, Carcillo JA, Linde-Zwirble WT. The epidemiology of severe sepsis in children in the United States. Am J Respir Crit Care Med 2003; 167:695-701.

7. Proulx F, Fayon M, Farrel CA. Epidemiology of sepsis and multiple organ dysfunction syndrome in children. Chest 1996; 109:1033-7.
8. Lukas SL, Schoendoer KC, Schuchat A. Trends in sepsisrelated neonatal mortality in the United States 19851998. Pediatr Infec Dis J 2004; 23:599-603.

9. Stoll BJ, Holman RC, Schuckat. Decline in sepsisassociated neonatal and infant deaths in the United States, 1979 through 1994. Pediatrics 1998; 102:1-7.

10. Feezor RJ, Oberholzer C, Baker HV. Molecular characterization of the acute inflammatory response to infections with gram negative versus gram positive bacteria. Infect and Immunity 2003; 71:5803-13.

11. Maar SP. Emergency care in pediatric septic shock. Pediatr Emerg Care 2004; 20:617-23.

12. Whicher J, Vienvenu J, Monneret G. Procalcitonin as an acute phase maker. Ann Clin Biochem 2001; 38:483-93.

13. O'Connor E, Venkatesh B, Lipman J. Procalcitonin in critical illness. Crit Care and Resusc 2001; 3:236-43.

14. Meisner M. Biochemical and clinical aspects. Dalam: Procalcitonin a new, innovative infection parameter, biochemical and clinical aspects, Edisi ke-3. StuttgartNew York: Georg Thieme Verlag; 2000. h.15-45.

15. Budiono S. Beberapa faktor petanda laboratorium yang berhubungan dengan diagnosis sepsis pada anak di RSUP Manado. Tesis. Manado: Universitas Sam Ratulangi 2003.

16. Jafari HS, Mc.cracken GH. Sepsis and septic shock: A review for clinicians. Pediatr Infect Dis J 1992; 11:739-49.

17. Putto A, Ruuskanen O, Meurman O. C-reactive protein in the evaluation of febrile. Arc Dis Child 1986; 61:24-9.

18. Hatherill, Tibby SM, Turner C. Procalcatonin and cytokine levels: Relationship to organ failure and mortality in podiatrist septic shock. Crit Care Med 2000; 28:2591-4

19. Chan YL, Tseng CP, Tsay PK. Procalcitonin as a marker of bacterial infection in the emergency department: an observational study. Crit Care 2004; 8:12-20.

20. Lopez AF, Cubells Cl, Garcia JJ. Procalcitonin in pediatric emergency departments for the early diagnosis of invasive bacterial infections in febrile infants: result of a multi center study and utility of a rapid qualitative test for this marker. Pediatr Infect Dis J 2003; 22:895-903.

21. Gendrel D, Raymond J, Assicot M. Measurement of procalcitonin levels in children with bacterial or viral meningitis. Clin Infect Dis 1997; 24:1240-2.

22. Somech R, Zakuth V, Assia A. Procalcitonin correlates with C-reactive protein as an acute phase reactant in pediatric patients. IMAJ 2000; 2:147-9. 